\title{
$Z n \mathrm{~S}$ e の光援助M B E 成長
}

\author{
非会員 松村信男，更家淳司（就工芸䌦大）
}

\author{
Photoassisted MBE Grow th of ZnSe \\ Nobuo Matsumura and Junji Saraie, Non-member (Kyoto Institute of Technology)
}

\begin{abstract}
We developed photoassisted MBE of $Z \mathrm{nSe}$ on GaAs(100) substrates using a He-Cd laser (441.6nm). The epilayer thicknesses were reduced by the irradiation during growth and also after growth. Photodesorption rate con stant of adatoms were obtained and it was clarified that these photodesorption were photo enhanced thermal desorption. The desorption was enhanced totally under the coexistence of the photogenerated electrons and holes at the epilayer surface. Adsorption and desorption processes of $\mathrm{Zn}$ and Se adatoms on the $\mathrm{ZnSe}(100)$ surface were also investigated by RHEED. Chopped irradiation was used during growth and it was revealed that the effects persisted about 5 ms after the light was turned off.

Reduction in the density of hillocks, extension of the critical thickness, increase in the intensities of free-exciton emissions and lowering of the epitaxial temperature $\left(150^{\circ} \mathrm{C}\right)$ were realized by photoassisted $\mathrm{MBE}$. These improvements due to the irradiation can be explained by the migration enhancement of surface adatoms by the irradiation. Light irradiation effects on doping of impurities were investigated. A model of selective transfer of photogenerated carriers is proposed and the behavior of surface adatoms is discussed.
\end{abstract}

キーワード： $2 \mathrm{nSe}$ ，光援助MB E，光脱離，光照射効果，低温成長，電荷移動モテル

\section{1. まえがき}

光援助分子線エピタキシー（MBE）法は，MBE成長 中に，成長層のバンドギャップ以上の光を成長層表面に照 射することにより，種々の効果が得られる成長法である。 この方法は，光照射により表面原子の荷電状態を变化させ， 吸着原子の振舞いを制御できる新しい結晶成長法として注 目されている。光援助M B E 法は初めCdTeの成長(1)で試み られ，その後ZnSe $(2,3), 2 \mathrm{nS}(4) や \mathrm{ZnS}_{\mathrm{x}} \mathrm{Se}_{1-x}(5)$ 等の II - VI 族化合物に適用されている。

我々は今までに，2nSe，2nS $\mathrm{Se}_{1-\mathrm{x}}$ の成長に光援助M B E 法を用い，次に挙げる光照射効果を見いだした。

(1)光照射した膜のフォトルミネッセンス(PL)の自由励起子 発光強度が增加する。このことは膜中の非発光セン夕密度 の城少を意味していると考えられ，光照射によって結晶性 が改善されることが明らかになった(2)。

(2)成長中の照射や成長後に照射した試料の膜厚が隇少した。 このことから物理及び化学吸着原子が光脱離することがわ かった(2)。

(3)照射光にHg-Xeランプを用い，種々のフィルタを挿入して 光照射エネルギーの偖存性を調へた結果，成長層のバンド ギャップエネルギー以上の光のみが, 光照射効果に有効で あることがわかった(5)。
本報告では，今まで明らかになった結果を基にし，光援 助M B E の成長機棈を解明する目的で, 光照射下での表面 吸着原子の振舞いを㮔々の方法で調へ，膜質への光照射効 果を明らかにし，最後に吸着原子の振舞いのモデルを提案 する。

\section{2. 実龄方运}

ZnSeのM B E 成長中にHe-Cdレーザ光 (441.6nm)を照射し た。入射角は䄪 $20^{\circ}$ ，照射強度は通常約 $250-300 \mathrm{~m} / \mathrm{cm}^{2}$ で,フ オトン密度は約 $5-7 \times 10^{17} / \mathrm{cm}^{2} \cdot \mathrm{s}$ である。照射強度は弱いの で基板の温度上异は無視できる。光を成長面の一部に照射 し，一回の成長で照射と非照射の試料を同時に得た。光断 続照射の実験では, チョッピングのテューティ比を $50 \%$ と し，1Hzから $20 \mathrm{kHz}$ まで周波数を変化させた。

基板はCr-0ドープの GaAs (100)を使用し，原料として6Nの $\mathrm{Zn}$, Se及びZnSを用いた。ドナ不純物として $\mathrm{Cl}\left(5 \mathrm{~N}\right.$ - up- $\left.\mathrm{ZnCl}_{2}\right)$ と7NのGaを,アクセプタ不純物として半導体グレードの $\mathrm{NH}_{3}$ と3NのLiを用いた。基板温度は $150-340^{\circ} \mathrm{C}$ 、VI族と而矮 の分子線強度比 $\left(\mathrm{J}_{\left.\mathrm{V}_{1} / \mathrm{J}_{1}\right)}\right)$ は 0.5 から2まで変化させた。成長 速度は約 $0.5 \mu \mathrm{m} / \mathrm{h}$ で, 主に 4 時間成長させた。

反射高速麗子線回折(RHEED) $(4 \mathrm{kV}, 5 \mu \mathrm{A})$ による表面観察の 実験では，その鏡面反射点強度から， $\mathrm{nnSe}(100)$ 面上の $\mathrm{n} n$ 及 びSe原子の吸着と脱離過程を調へた。この際GaAs基板上に 
ZnSeバッファ層を新 $2000 \AA$ 成長させた。電子線の入射力向は [011]で入射角は $87^{\circ}$ である。電子楾の照射強度は䄪 $100 \mathrm{~mW} /$ $\mathrm{cm}^{2}$ 上弱く，温度上昇は無視できる程度に小さい。

成長膜は山KのPL（励起光は超高王Hgランプからの365nm）， X線回折，RHEEDなどで評価した。

\section{3. 炎照射下での表面吸着原子の振舞い}

<3.1>吸着原子の光脱離鸪を通常のM B E 法で成 長後，成長温度を維持しつつ，成長膜に光照射すると膜 厚が咸少した。このことは，化学結合していた原子が，光 照射によって表面から瞈離したことを意味する。また後に 述べるように，物理吸着状態の原子も光脱離する。そこで， 各吸着状熊からのZn及びSe原子の光眖㒕を考虑した成長速 度方程式を求め，膜厚減少量から各脱離定数算出した(6)。

成長速度方程式は次のように与えられる。

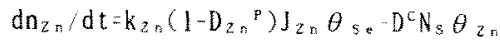

$$
\begin{aligned}
& d n_{s}=d t-k_{s}=\left(1-D_{s}{ }^{p}\right) J_{s \in} \theta_{z_{n}}-D^{c} N_{s} \theta_{s} \text {. } \\
& \theta_{z \mathrm{~s}}+\theta_{\mathrm{se}}=1
\end{aligned}
$$

ここで $n_{n}\left(n_{5}\right)$ は单位面皘あたりの化学吸着 $Z n(S e)$ 原子の 数、 $\mathrm{k}_{\mathrm{z}_{\mathrm{n}}}\left(\mathrm{k}_{\mathrm{s}}\right)$ は $\mathrm{Se}(\mathrm{Zn})$ 露出面上への $\mathrm{n}(\mathrm{Se})$ 原子の付着確率， $\mathrm{J}_{Z_{\mathrm{n}}}\left(\mathrm{J}_{\mathrm{S}_{\mathrm{e}}}\right)$ は $\mathrm{n}(\mathrm{Se})$ の分子線強度, $\theta_{Z_{\mathrm{n}}}\left(\theta_{\mathrm{Se}}\right)$ は Zn $(\mathrm{Se})$ 原子

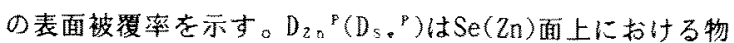
理吸着 $Z n(S e)$ 原子の光脱離定数（無次元）である。D㳊化 学吸着状態からのZnとSeの光脱䑾定数である。N Seの表面原子密度である。

化学吸着 $2 n$ 及びSe原子の脱雜定数の温度低存性を調べた 結果, 脱離定数は温度の增加と共に大きくなることがわか った。このことはこの脱離が光で促進された熱脱離であ ることを意味しており，光照射によって，化学吸着原子と

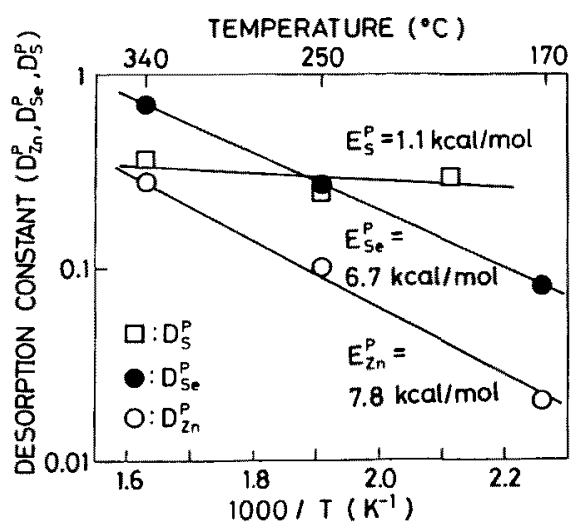

図 1 物理吸着状偟からのZn、Se及びSの光脱離定 数 $\left(D_{2 n}{ }^{P}, D_{S}{ }^{p}, D_{s}{ }^{P}\right)$ O温度低存性

Fig. 1. Temperature dependence of photodesorption constants $\left(D_{z s}{ }^{p}, D_{s} e^{p}, D_{s}{ }^{p}\right)$ of $Z n$, $\mathrm{Se}$ and $\mathrm{S}$ adatoms from the physical adsorp tion state.
その直下の原子との結合力が弱められたと考えられる。

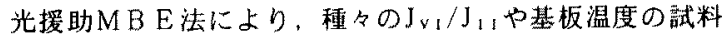
を作製し，膜景を測定すると，条件により減少量に違いが みられた。またこれらの娍少量は，上に述へた成長後の照 射の場合に比へ大きかった。この結果から，物理吸着状態 からのZn及びSeの脱離定数 $\left(D_{2 n}{ }^{p}, D_{s}{ }^{p}\right)$ 算出し, その温 度依存性を図 1 に示す。 $\mathrm{D}_{2 \mathrm{n}}{ }^{\mathrm{P}}$ 及びD心。 ${ }^{\mathrm{P}}$ は温度の减少之共に 隇少している。従って，物理吸着状嗭からのZn及びSeの光 脱離も光で促進された熱脱離であることがわかった。

$2 n \mathrm{~S}_{x} \mathrm{Se}_{\mathrm{x}-\mathrm{x}}$ の組成は，光照射に上って変化した。成長温度 が $200^{\circ} \mathrm{C}$ で $\mathrm{x}$ 和粷 $15 \%$ 减少し, $250^{\circ} \mathrm{C}$ 以上では增加 $340^{\circ} \mathrm{C} て ゙$ 䄪 2 倍)した。今，xの小さいZnS $\mathrm{Se}_{2-\mathrm{x}}$ にむけるSeの脱離 定数が，ZnSeのそれに等しいと仮定すると，Sの脱離定数 $\left(D_{\mathrm{s}}{ }^{\mathrm{P}}\right)$ の温度依存性は図1に示すようになる。Sの活性化工 ネルギーはSeのそれに比へかなり小さい。D ${ }^{\mathrm{P}}$ とDS。 ${ }^{\mathrm{P}}$ は2 250 ${ }^{\circ} \mathrm{C}$ 付近で交差する。

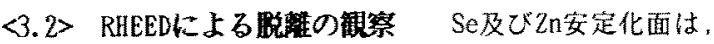
光や電子線を照射しない状態で，ZnSe面にそれぞれSeやZn 分子線を照射して作製した。Zn安定化面からの鏡面反射強 度は，Seのそれに比べ大きかった。ここでは他の報告(7)か ら, 反射強度の大きさが化学吸着Znの表面被䧗率に比例し ているとした。また䉓子楾照射も吸着・脱離に影響するの で, 吸着原子に及济す電子線と光照射の効果を考虑し，表 面化学吸着原子密度の速度方程式を求め,脱離之吸着の车 験から各脱離定数を算出した(8)。

その結果, 化学吸着Se原子の光脱嚄杜膜厚の減少量から 求めた值とよく一致し，この脱離過程が光で促進された熱 脱離であることが再確镬された。光照射によって，膜厚が 减少したということは，化学吸着Zn原子屯光脱蜼したこと を意味する。しかしZn安定化面からの鏡面反射強度は光照 射によって变化しなかったことから，化学吸着Zn原子の光 脱離が電子線照射によって拫制されていることがかかった。

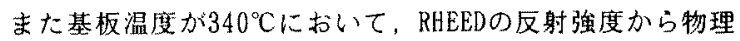
吸着状熊のSeの光脱離量を算出すると，ほぼ0となった。一 方，図1からDs ${ }^{\mathrm{p}}$ は的0.7と大きいことがかかる。このこと からRHEEDの電子線照射によって、物理吸着Se原子の光脱離 が強く抑制されていることがわかった。（ただしこの時， RHEEDの電子線によるSeの脱離量が大きく，その影響で光と 電子線の同時照射部の成長速度は減少した。）

<3.3> D C 電界印加 2nSeの光援助 M B E 成長中にD C 電界を印加した。電極を基板面から垂直方向へ $3 \mathrm{~cm}$ の位置 に設置し、電極にD C 電压+1000, 0、-1000Vを印加した（基 板は接地）。この実験の目的は，光生成された電子または 正孔を基板表面に選択的に集め，どちらのキャリアが光援 助M B Eに有効かを調へることである。正の笔压を印加す ることによって表面に䉓子を，俱の電圧で正孔を集めるこ とができると考えられる。成長後に電界を印加し，光照射 した場合の膜厚の減少速度や，成長中の同種の実矣による 漠厚の隇少率は，DC䉓界印加の下で，光照射のみの場合 に比へ，それぞれ䄪50\%及び15\%減少し，電压の極性にはよ 


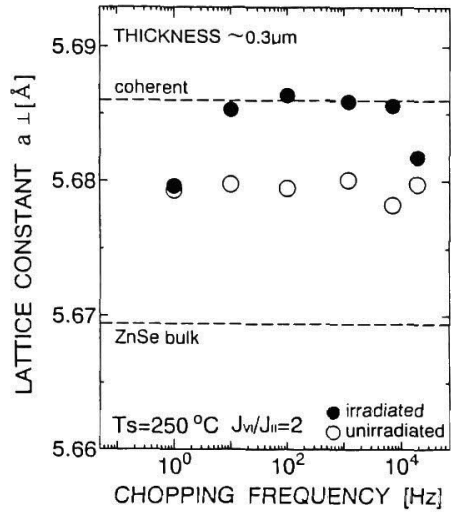

図 2 成長方向の格子定数 $(\mathrm{a} \perp$ )のチョッピング周 波数依存性

Fig. 2. Chopping-frequency dependence of the lattice constants normal to the epilayer surface.

らないことがわかった。このことから化学及び物理吸着状 態からの脱離は，光生成電子及び正孔両者の存在の下で全 体として促進されることがわかった。

く3.4>光チョッピンク周波数依存性図 2 に成長方向 の格子定数 $(\mathrm{a} \perp)$ のチョッピング周波数依存性を示す。膜厚

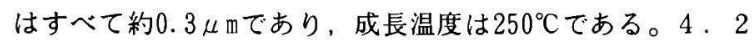
節の図 5 からわかるように, この膜厚において, 常時照射 膜ではコヒーレント成長し, 非照射膜では一部緩和してい る。1Hzの膜の $\mathrm{a} \perp$ は非照射のそれと同じ値を示しており， この周波数では光照射の効果がないことがわかる。10Hz以 上の膜ではコヒーレント成長しており, 光照射効果が明ら かにみられる。なお，20kHzにおいて，照射膜が一部緩和 している原因は不明であるが，図 3 の $20 \mathrm{kHz}$ のテータと考え 合わせると, 光照射効果はあると思われる。図 3 に照射と 非照射膜の自由励起子発光強度比のチョッピング周波数依 存性を示す。10Hz以下ではこの比は 1 であり, 光照射の効 果は見られない。100Hz以上では比は䄪2.5あり効果が見ら れる。図 2 と図 3 での光照射効果の臨界周波数の違いは, PLが格子定数に比へて, 結晶性を評価する手段として, よ り敏感であるということを示している。以上の結果から， 光遮断後 $5 \mathrm{~ms}$ 程度は光照射効果が維持されることがわかった。

\section{4. 㬺質への光照射效果}

《4.1> 表面モフォロジー 図 4 に照射と非照射膜の表

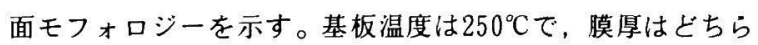

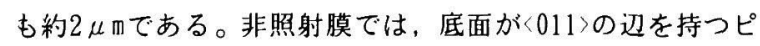
ラミッド状の多数のヒロックが見られる。このヒロックは

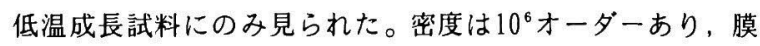
厚の減少と共に減少する傾向がみられた。この密度は光照 射によって104オーダーまで隇少した。なおこの隇少は, 光 照射による膜厚や成長速度の減少の効果ではないことを確

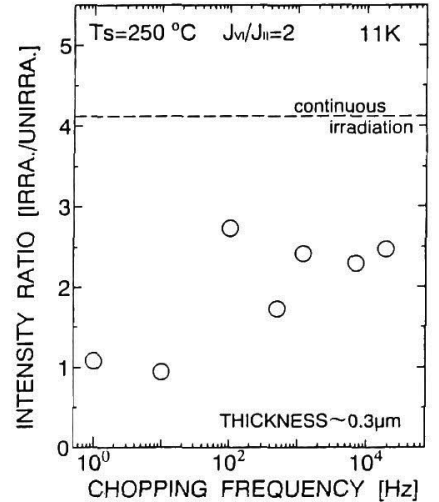

図 3 照射之非照射膜の自由励起子発光強度比の チョッピング周波数依存性

Fig. 3. Chopping-frequency dependence of the intensity ratios of the free-exciton emissions of the irradiated and the unirradiated epilayer.

かめてある。ヒロックの生成は, 成長温度がエピタキシー の限界温度に近いため, 表面吸着原子のマイグレーション が不十分となり，3 次元核成長した結果と考えられる。光 照射試料でヒロックの密度が咸少したのは, 光照射によっ て表面原子のマイグレーションが促進され, その結果 2 次 元成長が促進されたと考えられる。

4.2>膜厚依存性図 5 に成長方向の格子定数の膜厚 依存性を示す。基板温度は $250^{\circ} \mathrm{C}$ とし, 光は常時照射した。

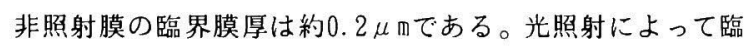
界膜厚が䄪 $0.35 \mu \mathrm{m}$ まで伸びることがわかる。非照射膜では, 3 次元成長による面内の不均一な圧縮之引っ張り歪の存在 によって，格子緩和が促進されたと考えられる。一方照射 膜では, 2 次元成長が促進された結果, 臨界膜厚が伸びたと 考えられる。ここで臨界膜厚が一般に報告されている值( $0.15 \mu \mathrm{m})$ に比へて大きい理由は明かではないが, 分子線強 度比や低温成長などの成長条件が関係していると思われる。

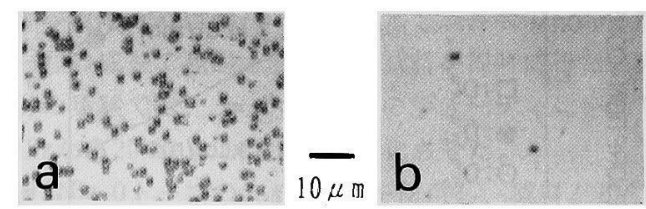

図 4 非照射(a)と照射膜(b)の表面モフォロジ一。 膜厚は(a) $2.1 \mu \mathrm{m}$, (b) $1.97 \mu \mathrm{m}$ である。成長時間は 4 時間で, 光照射強度は〜 $250 \mathrm{~m} / \mathrm{cm}^{2}$ であった。 Fig. 4. Surface morphologies of unirradiated (a) and irradiated (b) epilayers. Thicknesses are (a) $2.1 \mu \mathrm{m}$ and (b) $1.97 \mu \mathrm{m}$. The growth time was 4 hours and the irradiation intensity was about $250 \mathrm{~mW} / \mathrm{cm}^{2}$. 


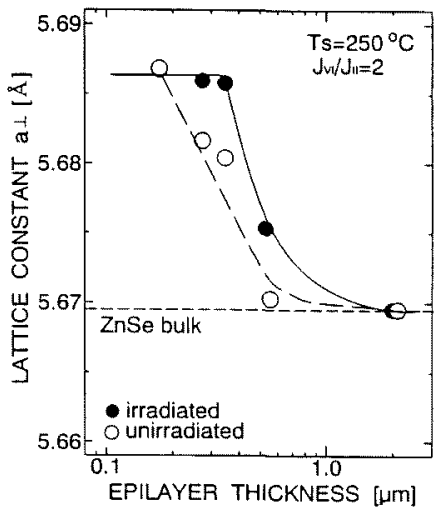

図 5 成長方向の格子定数 $(\mathrm{a} \perp)$ ) 膜厚依存性 Fig. 5. Thickness dependence of the lattice constants normal to the epilayer surface.

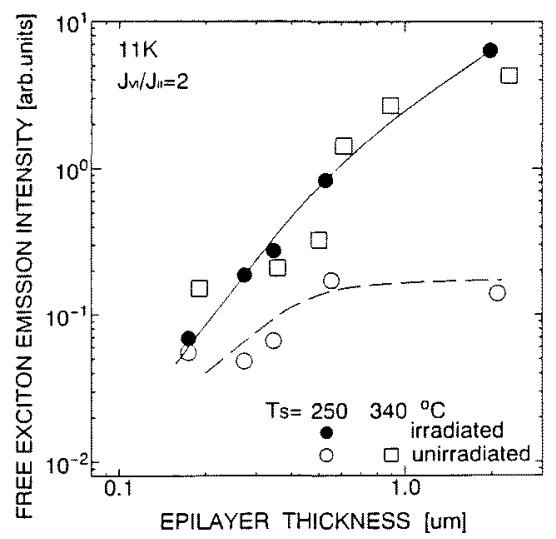

园 6 自由励起子発光強度の膜厚依存性

Fig. 6. Thickness dependence of the intensi ties of the free-exciton emissions.

图 6 にPLの自由励起子発光強度の膜㫗依存性を示す。基 板温度が $250^{\circ} \mathrm{C} の$ 非照射膜では, 強度は $0.6 \mu \mathrm{m}$ 以上で飽和す る。これは，PLの励起光の浸入梁さが浅いため, 発光領域 が0.6 $\mathrm{m}$ より小さいためと考えられる。光昭射によって発 光強度は大きくなり，この効果は膜厚の增加と共に顕著に なる。強度は非照射の最適成長温度 $\left(340^{\circ} \mathrm{C}\right)$ で作製した膜と 同程度である。照射によって強度が增加したのは，非発光 センタ一密度が減少し、結晶性が改善されたためと考えら

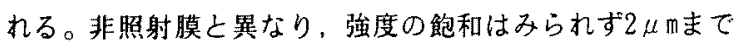
ほぼ直線的に增加する。このことは膜厚の增加と共に，成 長表面の結晶性が改善され続けていることを意味している。 このような改善は, 吸着原子のマイグレーションが基板温 度 $340^{\circ} \mathrm{C}$ の場合と同程度に促進されたことや, 膜厚の增加と 共に光生成キャリア数が增加したことによると考えられる。 光生成キャリアの增加は, He-Cd照射光のエネルギー (2.807
eV)がZnSeのバンドギャップに近いため，照射光の浸入深さ がPの励起光のそれに比べて大きいことによるものである。

図 1 からわかるように，物理吸着Se原子の脱離定数は2nの そ机に比へ大きいため，実効的な丁、1/、は隇少する。例え ば，基板温度が $250^{\circ} \mathrm{C} て ゙ は ， J_{v} / J_{1}$ が 2 の場合，照射部で は1.6になる。この実効的なっ、/小、の変化が, 上に述べた 結晶性の改善やヒロック密度の减少の原因かどうかを検討 するため，種々の $\mathrm{J}_{v_{1}} / \mathrm{J}_{1}$ ，の膜を成長させた。図 7 に自由励 起子発光強度の $\mathrm{J}_{\mathrm{V}_{1}} / \mathrm{J}_{\mathrm{I}}$ ，依存性を示す。非照射膜では $\mathrm{J}_{\mathrm{v}_{1}} /$ J、が1.5付近で強度が最大になるが, 光を照射することに よってどのコ、/J、においても，発光強度が增加しているこ

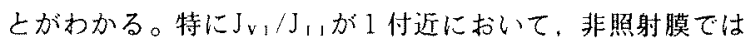
強度が急激に隇少するが，照射によって，さらに条件が悪 くなる(Zn-rich)にもかかわらず、強度が数桁改善されてい

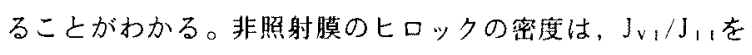
1.6にすることによって，105オーダーまで咸少できるが，

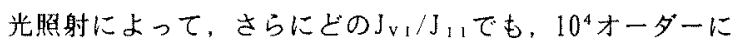
滅少できる。これらの結果から，光による結唱性の改善は，

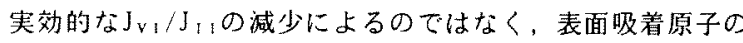
マイグレーションが光によって促進された結果であると結 論できる。

44.3>诋温成長 図 8 に光照射及び非照射膜のRHEED パターンを示す。基板温度が $250^{\circ} \mathrm{C}$ 以上では照射，非照射に かかわらず，RHEEDパターンは単結晶を示している。非照射 の条件でZnSeを単結晶成長させるには， $250^{\circ} \mathrm{C}$ 以上基板温 度が必要だった。(c)からわかるように，150 Cで成長した 照射強度 $300 \mathrm{~mW} / \mathrm{cm}^{2}$ の光照射膜は, 単結晶のRHEEDパターン

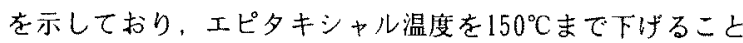
ができた。(e)は照射強度を(c)の $30 \%\left(90 \mathrm{~mW} / \mathrm{cm}^{2}\right)$ にした場合 （他の条件は同じ）で，配问性のある多結晶パターンを示 している。このことは，低温化の程度は光照射強度に依存 していることを意味しており，照射強度を大きくすれば， 更にエピタキシャル温度を下げることができると考えられ

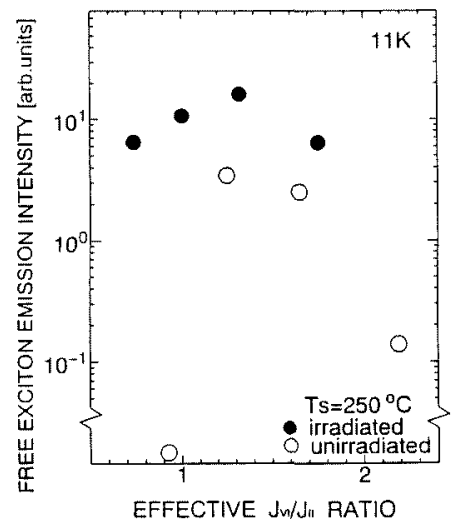

図 7 自由励起子発光強度のJ $\mathrm{v}_{1} / \mathrm{J}_{1}$ ，依存性 Fig. 7. $J_{1} / J_{1}$, ratio dependence of the intensities of the free-exciton emissions. 
る。なお，各成長膜 ( (a)-(e)) の膜厚は，それぞれ $(0.73,1.1,1.9,1.9,1.7 \mu \mathrm{m})$ であり, 成長時間は4時間一 定とした。(b)の非照射膜にくらべ(c)の光照射膜の膜厚や 成長速度は大きい。このことから光照射による低温化の原 因が, 膜厚や成長速度の減少によるものではないことがわ かる。図 9 に光照射膜 $\left(150^{\circ} \mathrm{C}, 300 \mathrm{~mW} / \mathrm{cm}^{2}\right)$ 之非照射膜 $(340$ ${ }^{\circ} \mathrm{C}$ (最適成長温度) ) のPLスペクトルを示す。自由励起子 発光強度は非照射膜のそれと同程度あり, 膜質が改善され ていることがわかる。なお $150^{\circ} \mathrm{C} て ゙$ 成長した多結晶の非照射 膜はほとんど光らなかった。

《4.4〉不純物ドーピング図10に光照射の下で各種不 純物を成長中添加したZnSeのPLスペクトルを示す。比較の ために，非照射膜のスペクトルも示す。(a),(b)はLi, (c), (d)はN, (e), (f)はGa, (g), (h)はClをドープした試料である。

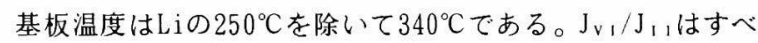
て約 1 とした。 $I_{1}{ }^{\mathrm{s}}$ または $\mathrm{I}_{2}$ 発光がどの試料にもはっきり現 れており, 浅いアクセプタ及びドナ準位が形成されている ことを示している。 $\mathrm{i}, \mathrm{N}$ 及びClの束縛励起子の発光強度は, 照射によって減少し, Gaのそれは增加した。発光強度の減 少（增加）か，光照射による不純物の取り込み量の減少 （増加）に対応していると仮定すると, 光照射が不純物添

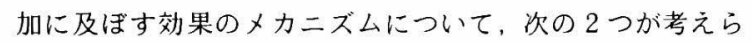
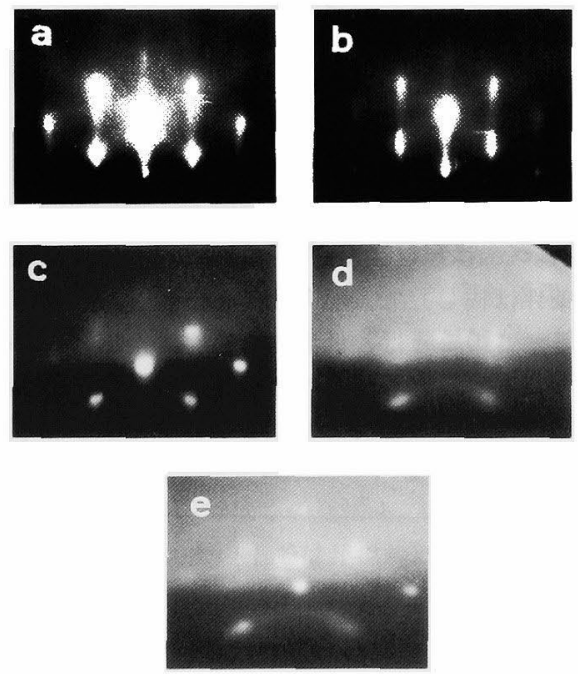

図 8 光照射及び非照射膜のRHEEDパターン。(a), （b)は基板温度か $250^{\circ} \mathrm{C},(\mathrm{c}),(\mathrm{d}),(\mathrm{e})$ は $150^{\circ} \mathrm{C}$ 。(a), (c)は $300 \mathrm{~mW} / \mathrm{cm}^{2}$ の光照射膜で(e)は $90 \mathrm{~mW} / \mathrm{cm}^{2}$ 照射。 (b), (d)は非照射膜。

Fig. 8. RHEED patterns of the grown layers with and without laser irradiation at substrate temperatures of 250 ( (a), (b)) and 150 ${ }^{\circ} \mathrm{C}$ ((c), (d) and (e)). (a) and (c) show pat terns with $300 \mathrm{~mW} / \mathrm{cm}^{2}$ irradiation, (e) with $90 \mathrm{~mW} / \mathrm{cm}^{2}$ irradiation. (b) and (d) show patterns without irradiation.

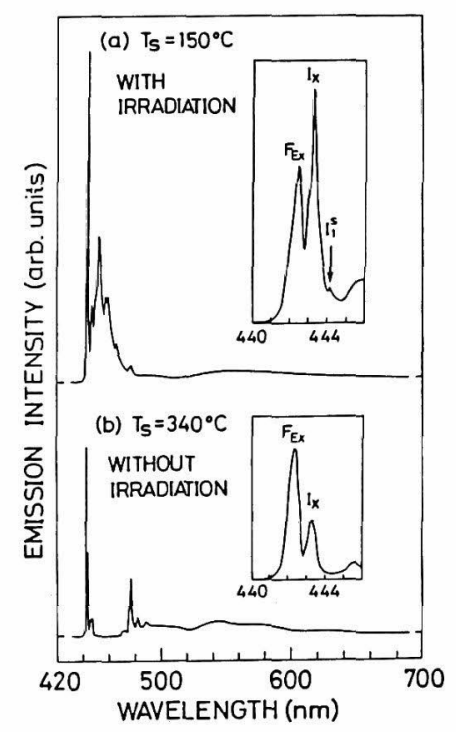

図 9 光照射膜 $\left(150^{\circ} \mathrm{C}, 300 \mathrm{~mW} / \mathrm{cm}^{2}\right)$ (a) と非照射膜 $\left(340^{\circ} \mathrm{C}\right.$ (最適成長温度) ) (b)のPLスペクトル Fig. 9. PL spectra of the grown layers. (a) shows the spectrum of the layer grown at $150^{\circ} \mathrm{C}$ with irradiation and (b) shows at $340^{\circ} \mathrm{C}$ (optimum growth temperature) without irradiation.

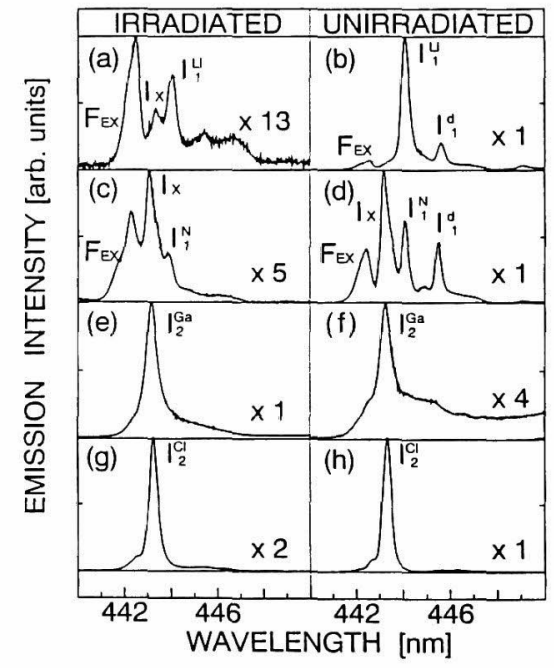

図 10 光照射の下で各種不純物を成長中添加し たZnSeのPLスペクトル。比較のために, 非照射膜 のスペクトルも示す。(a), (b)はLi, (c), (d)はN, (e), (f)はGa, (g), (h)はClをドープした試料。 Fig. 10. PL spectra of ZnSe epilayers doped with acceptor and donor impurities with and without irradiation: (a), (b) $\mathrm{Li}$; (c), (d) N; (e), (f) $\mathrm{Ga}$; (g), (h) Cl. 
れる。

(1)光照射によって，表面のストイキオメトリ一は翌化する。 この場合，図1からわかるようにSeの脱㓲量の方がZnのそ れに比べて大きいため，V蔟笡換の不純物(N及びC1)が取り 込ま机易くなり， I族置換の不純物( Li 及びGa)は取り込ま れにくくなると予想される。

(2)不純物の光脱離定数がSeやZnのそれに比べて異なるため, 不純物の取り込み量が変化する。

実験結果では、Nは取り込まれにくくなり，Gaは取り込ま れ易くなっており(1)で考えだカニズムに反する。Liにつ いては(1)の可能性が考えられるので検討した。非照射の条 件でJ $\mathrm{V}_{1} / \mathrm{J}_{1}=0.5$ の試料を作製し，比が 1 の試料と比較した。 その結果、【い強度の隇少は見られなかった。このことは 取り込み量減少のメカニズムが(1)ではなく，(2)であること を示唆している。なおClに関しては，電気的测定の結果， 光照射の不純物取り込み量への影響はほとんどないことが わかった。

以上をまとめると，光照射による不純物の取り込み量の 変化は, 光照射による表面ストイキオメトリ一の変化によ るのではなく，不純物の光脱離定数と，不純物が置換する ZnあるいはSe原子の光脱離定数との違いによって決まると 考えられる。

\section{5. 吸着原子找舞いのモテル}

今までに明らかにされた種々の光照射効果を説明するた め，表面原子の振舞いのモデルを提案する。成長膜のバン ドギャップ以上のエネルギーの光が照射効果に有効である こと(5)から，膜中で光生成されたキャリアが最表面の化学 吸着原子に選択的に電荷移動するモテルを考えた。ます非 照射時においては，最表面Se原子の荷電状態はZnとSeの化 学結合ボンドの強いイオン性のため負と考えられる。膜中 で光生成された正孔は表面Se原子を中性化するように移動 する。この表面状態の変化は，最表面の化学吸着Se原子と その直下のZn原子との化学吸着力を弱另をに，物理 吸着力を弱兴考えられる。以上の変化は最表面のZn原 子に光生成された電子が移動することによっても同様に起 こると考えられる。

上に述へたモテルで光照射効果が良く説明できる。吸着 原子の吸着力の隇少によって, 光脱囄し易くなると説明で きる。最表面原子の荷電状態の变化によって, 物理吸着原 子の吸着力が減少し，その結果，物理吸着原子が動き易く なると考えられる。このことにより，3次元成長しにくく なるため, 表面モフォロジーが改善され, 臨界膜厚は増加 する。また、マイグレーションの促進によって, 物理吸着 原子は本来の化学吸着サイトに到達しやすくなるため、工 ピタキシャル成長温度は低下すると説明できる。光生成電 子及び正孔の選択的移動モテルから，両キャリアの共存の 下で全体として脱離が促進された結果も説明できる。すな わち，電子（正孔）のみの電荷移動であれば，Zn(Se)のみ が中性化さ机るが，両方のキャリアが共存することによ。
て，Zn及びSe両者が中性化され，昅着原子の脱離がより促 進さ机ると考えられる。3，4節で明らかになった光照射 効果の持続時間( $5 \mathrm{~ms}$ 程度)は, ZnSeバルク内の光生成キャリ アの寿命( $85 \mathrm{ps}$ )(9)に比べ非常に長く，表面付近でのキャ リアの振舞いを考虑しなければならない。そこで(100)成長 表面を考えると， $\mathrm{n}$ 亡Se両方が露出しているため，上に述 べた選択的電荷移動モデルを適用すれば，光生成電子はZn に，正孔はSeに移動し，キャリアは空間的に分離するため， これらのキャリアは再結合しにくくなり，表面荷電状態の 変化は光がオフになった後も長い時間続く上考えられる。

\section{6. むすひ}

ZnSeのMB E 成長中にHe-Cdレーザ光を成長表面に照射し， その成長膜を評価した。光照射下での表面吸着原子の振舞 い，膜質への光照射効果を明らかにし，吸着原子への光生 成電子及び正孔の選択的移動モデを提案した。

現在，ZnSe系半導体を用いた青緑色レーザは，比較的低 温で成長させる必要があるが，低温成長による活性層の結 晶性劣化の改善が重要な課題である。本報告に述べた光援 助M B E 法を用いれば，低温成長膜の結晶性を改善できる ので，デハイス作製にも有効な手法と考えられる。

(平成6年3月22日受付, 同6年8月1日再受付)

\section{文献}

(1) R. N.Bicknell, N.C.Giles and J.F. Schetzina: "Growth of High Mobility n-type CdTe by Photoassisted Molecular Beam Epitaxy" Appl.Phys. Lett.. 49. 17. 1095 1097(1986)

(2) N. Matsumura, M. Tsubokura and J. Saraie: "Laser Irradiation During HBE Growth of $\mathrm{ZnS}_{\mathrm{x}} \mathrm{Se}_{1-\mathrm{x}}$ : A New Growth Parameter" . J.Crystal Grokth, 101. $1-4,61 \sim 66(1990)$

(3) M. Ohishi, H. Saito, H. Torihara, Y. Fujisaki and K Ohmori: "Ultraviolet Irradiation Effect on the MBE Grow th of $2 \mathrm{nSe} / \mathrm{GaAs}$ Obserbed by RHEED" , J. Crystal Growth, 111, 1-4.792 796(1991)

(4) M. Ki tagawa, Y. Tomomura, K. Nakanishi, A. Suzuki and S. Nakajima: "Photo-assisted Homoepitaxial Growth of ZnS by Holecular Beam Epitaxy" , /. Crystal Grokth, 101, 1-4,52 55(1990)

(5) N. Matsumura, M. Tsubokura K. Miyagawa, N. Nakamura, Y.Miyanagi, T. Fukada and J.Saraie: "Molecular Beam Epitaxial Growth of $2 \mathrm{nSSe}$ with Hg-Xe Lamp Irradiation" . Jph.J.Appl.Phys., 29, 5, L723 L726(1990)

(6) N. Matsumura, T. Fukada, K. Senga, Y. Fukushima and J.Saraie: "Photo-assisted MBE Growth of $Z \mathrm{nSe}$ on GaAs Substrates" , J.Crystal Grokth, 111,1-4. $787 \sim 791(1991)$ 
( 7 ) Z. Zhu, M. Hagino, K. Uesugi, S. Kamiyama, M. Fujimoto and T. Yao: "Surface Processes in ALE and MBE Growth of $\mathrm{ZnSe}$ : Correlation of RHEED Intensity Variation with Surface Coverage" . Jpn. J.Appl. Phys., 28.9,1659 1663(1989)

(8) N. Matsumura, K. Senga, J. Kakuta and J.Saraie: "Reflection High Energy Electron Diffraction Study on the Adatom Desorption from the ZnSe Surface under Electron Beam Irradiation and Light Irradiation" , J.Crystal Growth, 117,1-4, 129 133(1992)

(9) J. A. Bolger, I. Galbraith, A. K. Kar, J.Simpson, S. Y. Hang, K.A.Prior, B.C.Cavenett and B.S. Wherrett: “Band-edge Refractive 0ptical Nonlinearities in Molecualr Beam-grown ZnSe Epilayers" , App/.Phys.Lett., 63, 6, 709 711(1993)
松村 信男 (非会員) 1949年6月16日生まれ。76年3月 京都工芸繊維大学大学院 (電気工学専攻) 修了。同年同大学工業短期大学部勤務。 GaAs基板に格子整合したZnSSeのMBE成長と その評価, $2 n S S e$ 光援助MBE法に関する研 究に従事。現在同大学工芸学部電子情報工 学科助手。

更家 淳司（非会員）1943年12月11日生まれ。68年3月 京都大学大学院（電気工学第 II 専攻）修了。 同年同大学勤務。CdTe-CdS混晶, アモルフ アス半導体の研究, ZnSSeのMB E 成長, ア ルミナ膜の C V D , SiCの結晶成長などに従 事。現在京都工芸織維大学工芸学部電子情 報工学科教授。工博。 